\title{
Un par de satrapías en el Caribe. Autoritarismo dominico-venezolano en la caricatura política de El Tiempo, 1958-1960 ${ }^{1}$
}

Doi: $10.25100 /$ hye.v14i50.6488

Artículo recibido: 28-03-2017 | Artículo aceptado: 24-10-2017

\section{Andrés Murcia Neira}

Historiador de la Universidad Nacional de Colombia, (Colombia). Pertenece al grupo de investigación Estudios Históricos Comparativos, Universidad Nacional, (Colombia). Entre sus últimas publicaciones se encuentran: Murcia Neira, Andrés, "«Cipriano Castro: El Hombre del Destino» Representaciones caricaturales del «Bloqueo pacífico», 1902-1903“, Revista Historia para Todos. Claves para entender nuestro tiempo (Tucumán: Año III, No. 5: 2017) ISSN: 2451-6333; Murcia Neira, Andrés, "El Bombardeo de la Plaza de Mayo en la caricatura política de «El Tiempo»: un estudio de caso desde el Análisis Multimodal del Discurso en los sucesos argentinos de junio de 1955", Goliardos. Revista Estudiantil de Investigaciones Históricas, (Bogotá: Año XXII, No. 20: 2016) ISSN: 2145-986X; y Murcia Neira, Andrés, "Estado Novo, Velho Debate. Portugal entre la encrucijada AtlánticoMediterránea y la reproducción de un paisaje Imperial ajardinado. (1934-1938)", Quirón. Revista de Estudiantes de Historia (Medellín: Vol. III, No. 6: Enero-Junio de 2017) ISSN 2422-0795. Correo electrónico: amurcian@unal.edu.co

Forma de citar este artículo: Murcia Neira, Andrés. “Un par de satrapías en el Caribe. Autoritarismo dominico-venezolano en la caricatura política de El Tiempo, 1958-1960". Historia y Espacio, vol. 14, n 50 (2018): 85-117. Doi: 10.25100/hye.v14i50.6488.

1 Artículo de investigación. 


\section{Un par de satrapías en el Caribe. Autoritarismo dominico-venezolano en la caricatura política de El Tiempo, 1958-1960}

Resumen: Remitiéndose a los momentos finales de las dictaduras de Marcos Pérez Jiménez, en Venezuela, y Rafael Leónidas Trujillo, en República Dominicana, este artículo devela las caracterizaciones adjudicadas a aquellos regímenes desde la caricatura política de filiación frentenacionalista. Se examina cómo tales representaciones incidieron sobre el escenario colombiano de inicios del Frente Nacional. Las viñetas analizadas fueron publicadas en el diario capitalino El Tiempo, creadas por dos de los principales caricaturistas de opinión del país: Aldor y Chapete. Sus obras permiten apreciar las nociones de criminalidad, represión e inestabilidad asociadas al autoritarismo latinoamericano ante el naciente régimen democrático bipartidista en Colombia.

Palabras clave: Caricatura política, represión, criminalidad, inestabilidad, autoritarismo latinoamericano.

\section{A pair of satrapies in the Caribbean. Dominican-Venezuelan authoritarianism at El Tiempo's political caricature, 1958-1960}

Abstract: Referring to the final moments of both dictatorships of Marcos Pérez Jiménez in Venezuela, and Rafael Leonidas Trujillo in the Dominican Republic, this article unveils the characterizations awarded to those regimes since the Colombian political caricature. It examines how such representations affected the Colombian scenario of the beginnings of the Frente Nacional. The cartoons analyzed were published in the newspaper El Tiempo, and created by two of the country's leading cartoonists: Aldor and Chapete. His works allow us to appreciate the notions of criminality, repression and instability linked with Latin American authoritarianism before the newly democratic regime in Colombia.

Keywords: Political caricature, repression, criminality, instability, Latin American authoritarianism. 
Un par de satrapías en el Caribe. Autoritarismo dominico-venezolano en la caricatura política de El Tiempo, 1958-1960

\section{Introducción}

El presente artículo examina las representaciones construidas en torno a dos casos de autoritarismo latinoamericano desde la prensa colombiana, mediante la articulación entre la caricatura política, editoriales y reportajes publicados en el periódico El Tiempo sobre la dictadura venezolana y dominicana.

Se observará cómo la difusión de tales representaciones incidió en el escenario político colombiano, donde el recién instaurado Frente Nacional necesitaba atribuirse una imagen democrática y civilista a fin de contrarrestar cualquier manifestación de simpatías hacia el depuesto Gustavo Rojas Pinilla, percibido entonces como personalización local del autoritarismo aún subsistente en América Latina a finales de los años cincuenta.

Usualmente la investigación sobre las dictaduras latinoamericanas del siglo XX que trata de caracterizar los regímenes autoritarios desde fuentes no convencionales para la historia, recurre a la observación de obras literarias a fin de suplir los vacíos de la historia oficial recluida en los archivos gubernamentales, a fin de perfilar las representaciones de la memoria colectiva de un periodo determinado a través del ámbito artístico, mayoritariamente el novelístico ${ }^{2}$. Las caricaturas también desempeñaron un rol activo en la

2 En el caso dominicano, Ignacio López Calvo, publicó en 2005, God and Trujillo. Literary and cultural representations of the Dominican Dictator. Convencido de la escasa atención académica prestada a la producción cultural del Trujillato, seleccionó un corpus de novelas 
Un par de satrapías en el Caribe. Autoritarismo dominico-venezolano en la caricatura política. Andrés Murcia Neira

construcción de las representaciones de las principales figuras dictatoriales, difundidas a lo largo de América Latina, a fin de acentuar las inconveniencias acarreadas por la instauración de regímenes de fuerza en países donde ya comenzaban a verse visos de gobiernos abiertos a una participación política algo más amplia.

El presente examen se centrará en dos de las principales figuras del panorama dictatorial caribeño subsistentes entre 1957 y 1960: Marcos Pérez Jiménez (1952-1958) y Rafael Leónidas Trujillo (1930-1961). Estos personajes ante la prensa colombiana sintetizaron los vicios inherentes a los sistemas autoritarios de esta parte del hemisferio, exponiendo las inconveniencias de un eventual regreso en Colombia de los regímenes contrarios a los valores democráticos representados por el Frente Nacional ${ }^{3}$.

de autores como Mario Vargas Llosa, Gabriel García Márquez, Manuel Vázquez Montalbán, Enrique Lafourcade y Edwidge Donticat para emprender un análisis sobre temáticas como las políticas del régimen sobre la venganza, la desmitificación de la resistencia anti-trujillista, la lucha de la mujer contra la dictadura y la idealización del pueblo oprimido asociado con las comunidades indígenas de Taínos. Su objetivo es identificar las representaciones narrativas elaboradas sobre la dictadura trujillista desde la literatura latinoamericana. Y para el caso venezolano, fue publicado en 2001 La dictadura de Pérez Jiménez: testimonio y ficción, por María Dolores Galve de Martín. La autora seleccionó un corpus de cinco novelas publicadas en la década posterior a la caída del general andino. Arguyendo la ausencia de estudios venezolanos sobre la temática de dictadura, Galve de Martín procuró caracterizar los elementos reiterativos presentes en las representaciones literarias de la dictadura perezjimenista a fin de identificar el discurso cultural construido alrededor de ella. Ver: Ignacio López Calvo, God and Trujillo. Literary and Cultural Representations of the Dominican Dictator (University Press of Florida, 2005) y María Dolores Galve de Martín, La dictadura de Pérez Jiménez: Testimonio y ficción (Caracas: Universidad Central de Venezuela/ Consejo de Desarrollo Científico y Humanista, 2001).

3 En el ámbito de la historiografía colombiana, las investigaciones sobre la caricatura política se han centrado, como es comprensible, sobre el trabajo de artistas nacionales, enfocados en temas de carácter doméstico. No ha sido objeto de gran atención el escenario político de la zona Caribe. En términos generales grande ha sido la relevancia obtenida por la obra de Germán Arciniegas, El Zancudo: la caricatura política en Colombia, publicada en 1975. En esta sigue la trayectoria del caricaturista Alfredo Greñas (1856-1949), quien desplegó su trabajo durante la Regeneración, ante la cual se mostró como un férreo opositor al régimen, valiéndose de la caricatura como instrumento de expresión contra el proyecto de país propuesto por Rafael Núñez y Miguel Antonio Caro. Asimismo, es ineludible la referencia a la obra de Germán Colmenares, publicada en 1984, titulada Ricardo Rendón: una fuente para la historia de la opinión pública, en la cual emprende una recopilación de la obra de Ricardo Rendón (1894-1931), acompañándola de una contextualización alrededor de la versatilidad temática adoptada por él, incluyendo dentro de su tratamiento el célebre Tratado Urrutia-Thompson 
El artículo se divide en cuatro partes. La primera esboza algunas precisiones teórico-conceptuales relacionadas con el carácter de la caricatura política como fuente histórica, y de las noticias y editoriales como constructores discursivos de representaciones. La segunda parte analiza las caracterizaciones descriptivas sobre Pérez Jiménez entre diciembre de 1957 y enero de 1958, con ocasión de su derrocamiento. La tercera parte esboza un desarrollo similar de las representaciones construidas sobre Trujillo, en ocasión de la crisis diplomática interamericana sufrida por su régimen debido al respaldo clandestino brindado a una insurrección militar venezolana y el atentado terrorista contra el presidente de Venezuela, Rómulo Betancourt, ambos acontecimientos ocurridos entre abril y agosto de 1960. En la cuarta parte se traza un cotejo entre las representaciones dadas a ambas dictaduras, orientado a identificar su funcionalidad en el panorama colombiano de establecimiento del Frente Nacional, el cual, a través del gobiernista y más importante periódico colombiano del momento (El Tiempo), aspiró granjearse legitimidad descalificando a los potenciales enemigos continentales del régimen bipartidista.

A fin de efectuar la citada observación, se contó con un corpus de viñetas dibujadas por el principal dúo de caricaturistas de El Tiempo quienes le

de 1914. A través de la Biblioteca Luis Ángel Arango, el Banco de la República ha demostrado interés en acometer la recuperación documental de la caricatura colombiana, a fin de contribuir con la reconstrucción de su historia en el país. Hasta el momento su labor más encomiable ha sido la exposición La caricatura en Colombia a partir de la Independencia, abierta entre el 2 de diciembre del 2009 y el 15 de junio de 2010. Bajo la curaduría de Beatriz González Aranda, tal exposición se materializó en la publicación, en 2009, de un libro homónimo, que recoge doscientos años de historia, a través de la reproducción de las obras que retrataron los principales acontecimientos del país. Rubén Darío Acevedo Carmona, con su libro Política y caudillos colombianos en la caricatura editorial, 1920-1950, publicado en 2009, aborda la caricatura, como fuente documental útil para emprender la reconstrucción de los imaginarios políticos, dilucidados en torno a dos figuras centrales del escenario colombiano de mediados del siglo XX: Jorge Eliecer Gaitán (1903-1948) y Laureano Gómez (1889-1965). Pone de manifiesto, cómo la caricatura contribuyó a la construcción de identidades partidistas, en un periodo caracterizado por una violencia en el plano oral, escrito y físico. Como se puede apreciar, las investigaciones alrededor de la caricatura política producida en Colombia no han dado espacio al análisis de temas que trasciendan más allá de las fronteras del país. Aún están por analizarse procesos populistas, dictaduras, regímenes militares o transiciones democráticas, con amplio impacto en América Latina y que desde la caricatura colombiana del momento ineludiblemente captaron la atención de los artistas editoriales, conscientes de las ramificaciones que tales procesos continentales tendrían sobre el escenario colombiano. 
Un par de satrapías en el Caribe. Autoritarismo dominico-venezolano en la caricatura política.

Andrés Murcia Neira

brindaron cobertura a los acontecimientos venezolanos y dominicanos del momento: Chapete y Aldor $^{5}$.

\section{La caricatura política como forjadora de representaciones}

Puede la caricatura ser entendida como la representación visual de individuos o sujetos determinados, cuyas principales características fisionómicas son objeto de distorsión y exageración, con el fin de transmitir una imagen hilarante a partir de la degradación personal ${ }^{6}$. En la definición de su faceta política, la caricatura ha de ser entendida como la ridiculización visual de personajes y colectivos involucrados en las luchas por el poder dentro de la sociedad ${ }^{7}$.

4 Hernando Turriago Riaño (1923-1997), desde 1944 trabajó como caricaturista en El Tiempo, donde ejerció su labor durante cuarenta años. El sello de sus obras consistía en un pequeño huevo caracterizado por expresar una emoción ante cada una de las situaciones caricaturizadas: el "Chapetín". Insigne opositor al régimen de Gustavo Rojas Pinilla (1953-1957), burló la censura mediante caricaturas con subrepticios significantes dirigidos a criticar al gobierno militar, sin embargo, ello no fue suficiente para que muchas de sus caricaturas fuesen censuradas. Aunque su principal foco de atención era la situación política colombiana, ocasionalmente dedicó algunas de sus viñetas a retratar episodios del panorama político latinoamericano como el auge y caída de los populismos, los desmanes de las dictaduras militares, o la Revolución cubana. Las viñetas pusieron de manifiesto su orientación anticomunista.

Martha Lilian Pinto Malaver, "! Dictadores! A discreción. Una mirada desde la caricatura de Chapete” Historia Caribe vol. IX, N. ․ 25 (julio - diciembre 2014): 278

5 Peter Aldor (1904-1976), caricaturista e ingeniero húngaro. Colaboró con el periódico Democracia U.J.Magyarorszag entre 1945 y 1946. Luego se trasladó a Francia y trabajó como caricaturista de la agencia France Press de París, y Ringler Verlag de Zúrich, entre 1947 y 1948. Llegó a Colombia a finales de 1948 y al año siguiente publicó su primera caricatura en El Tiempo. Sus temas de interés fueron las fricciones de la posguerra europea y norteamericana, la expectativa ante una eventual guerra nuclear, junto con una sempiterna reprobación a las dictaduras militares, que entonces proliferaban en América Latina, socavando la libertad de prensa y suprimiendo de manera violenta todo remanente de oposición política. Carmen Ortega Ricaurte, Diccionario de artistas en Colombia (Bogotá: Ediciones Tercer Mundo, 1965), 26-27.

6 No obstante, también es un medio para la exaltación de valores y actitudes morales de personalidades o concepciones del mundo determinadas. Pero tales referencias han de resultar peligrosas al asentarse sobre una línea divisoria entre lo real y lo falso. Charles Press, The Political Cartoon (Rutherford, N. J.: Fairleigh Dickinson University Press; Toronto: Associated University Presses, 1981), 19

7 Lawrence Streicher, “On a Theory of Political Caricature”, Comparative Studies in Society and History 9, 4 (July 1967): 431. 
La caricatura política más que entretener, pretende predisponer e influir en la actitud y opinión del lector en relación con situaciones políticas específicas, tal como lo hace un editorial ${ }^{8}$. Su valoración como fuente para la historia radica en su funcionalidad como "recurso para la conformación y control de imaginarios colectivos ${ }^{-9}$. Ella suele valerse del despliegue de recursos como la "sátira destructiva", proclive a develar los vicios atribuidos a los personajes objeto de representación, bajo connotaciones crueles e hirientes a fin de degradarlos y ridiculizarlos ${ }^{10}$.

Ante ello, la caricatura ha de constituirse en un texto visual polisémico, inscrito dentro de una amplia red de discursos ${ }^{11}$, por lo cual suele hallar en las fuentes de tipo textual un complemento para afianzar su mensaje. No es casual que las viñetas sean emplazadas en las páginas editoriales, dando lugar al denominado "lenguaje de la caricatura", consistente en la interacción entre palabra e imagen a fin de trascender el potencial comunicativo individual de cada medio ${ }^{12}$.

Por consiguiente, los titulares que encabezan las noticias adquieren relevancia como instancia de control sobre las interpretaciones previas y posteriores de las informaciones presentadas ${ }^{13}$. Debe el lector inferir los temas desarrollados a través de una inmersión detallada en los titulares y encabezados, depositarios de significaciones positivas o negativas, fortalecidas por la repetición de expresiones que se adhieren a los modelos del mundo que cada uno de los lectores ha ido construyendo a lo largo de sus vidas, dando así lugar a proposiciones fáciles de memorizar ${ }^{14}$.

8 Charles Press, The Political Cartoon, 13.

9 Fausta Gantús, "Las caricaturas y la historia política. El caso del México decimonónico", PolHis. Boletín Bibliográfico Electrónico del Programa Buenos Aires de Historia Política, año 6 , N. ${ }^{\circ} .11$ (enero-junio 2013): 14

${ }^{10}$ Charles Press, The Political Caricature, 76.

${ }^{11}$ Graciela Sánchez Guevara, "La caricatura política: sus funcionamientos retóricos”, Razóny Palabra, N. 78 (noviembre-enero 2011-2012): 1.

12 Victor S. Navasky, The Art of Controversy (New York: Alfred A. Knopf, 2013), 23; Louis A. Pérez, Cuba in the American Imagination. Metaphor and the Imperial Ethos (Chapel Hill: The University of North Carolina Press, 2008), 132; Lawrence Streicher, "On a Theory", 428.

13 Teun A. van Dijk, La noticia como discurso. Comprensión, estructura y producción de la información (Barcelona: Paidós Ibérica, 1990 [1980]): 59-61.

${ }^{14}$ Ibíd., 125. 
Debido a la labor conjunta de la caricatura, del editorial y la noticia en la construcción de representaciones sobre personajes y entidades determinadas, la definición de representación aquí adoptada es la planteada por Roger Chartier, quien la percibe bajo dos sentidos aparentemente contradictorios. Por un lado, la entiende como la exposición de una ausencia, donde se torna necesario distinguir entre lo que se representa y lo representado. Y por otra parte, le percibe como la exhibición de una presencia, la presentación pública de algo o alguien ${ }^{15}$. Chartier se decanta por la primera acepción, precisando que las imágenes adscritas a tal sentido, tienden a sustituir al objeto ausente por algo que pudiera o no parecérsele ${ }^{16}$.

El cubrimiento caricatural es susceptible de adquirir connotaciones propagandísticas. Según la definición de propaganda dada por el Instituto para el Análisis de la Propaganda a finales de los años treinta, esta consiste en la expresión de opiniones o acciones por grupos o individuos, deliberadamente diseñadas para influenciar las opiniones o acciones de otros individuos con relación a fines específicos ${ }^{17}$. Posteriormente se han elaborado definiciones dirigidas a delimitar el accionar de la propaganda a situaciones de controversia ${ }^{18}$, donde la repetición sistemática de rótulos descriptivos fija representaciones denotativas de los personajes representados ${ }^{19}$.

En el presente examen, tales rótulos descriptivos han de ser denominados "aspectos criteriales". Según Gunther Kress y Theo van Leeuwen, los personajes u objetos de referencia nunca son totalmente representados, solo lo son los aspectos movilizados por el interés particular del elaborador de la representación, de acuerdo con su aspiración primigenia de degradar o exaltar, lo cual se denomina "criterial aspect of the object" ${ }^{20}$.

15 Roger Chartier, El mundo como representación. Estudios sobre historia cultural (Barcelona: Editorial Gedisa, 2005 [1983]), 57.

${ }^{16}$ Roger Chartier, El mundo como representación, 58.

17 William Garber, "Propaganda Analysis -To What Ends?", American Journal of Sociology vol. 48, N. 2 (September 1942): 240.

18 Charles Hoffer R., "A Sociological Analysis of Propaganda", Social Forces vol. 20, N. 4 (May1942): 446..

${ }^{19}$ Ibíd., 446.

${ }^{20}$ Gunther Kress y Theo van Leeuwen, Reading Images. The Grammar of Visual Design (New York: Routledge, 2006 [1996]), 7-13. 


\section{Facetas del perezjimenato en la caricatura colombiana}

La dictadura venezolana se inscribió en un escenario caribeño rebosante de regímenes militares, los cuales reprimieron todo movimiento de orientación democrática o de izquierda por considerarlos expresiones proclives al comunismo. Dictaduras como las de Rafael L. Trujillo, en República Dominicana (1930-1961); Anastasio Somoza García, en Nicaragua (19371956); Fulgencio Batista, en Cuba (1952-1958); Carlos Castillo Armas, en Guatemala (1954-1957) y François Duvalier, en Haití (1957-1971) se alinearon con Estados Unidos en la condena contra el comunismo, expresada en acuerdos como el Tratado Interamericano de Asistencia Recíproca, de 1947; la Carta de la Organización de Estados Americanos, de 1948; y la Declaración de Caracas. de $1954^{21}$.

Fueron grandes los esfuerzos del régimen perezjimenista por mostrarse ante la opinión interamericana, como el adalid de la prosperidad material subyacente a una eficaz gestión económica. Tal prosperidad era materializada en una red de grandes obras de infraestructura construida durante los seis años del régimen, con el objetivo de atenuar la excesiva dependencia de la economía hacia la exportación petrolera. En el marco programático del Nuevo Ideal Nacional ${ }^{22}$, su intención fue proyectar la imagen de un gobierno firmemente cimentado en el bienestar material de los venezolanos, suprimiendo las condiciones conducentes al surgimiento de cualquier disturbio social que perturbara el

${ }^{21}$ Stephen G. Rabe, Eisenhower and Latin America: The Foreign Policy of Anticommunism (Chape Hill and London: The University of North Carolina Press, 1988), 89-90.

${ }^{22}$ La doctrina del Nuevo Ideal nacional fue enunciada por vez primera el 13 de marzo de 1949, en discurso dado por el entonces teniente coronel Marcos Pérez Jiménez, en clausura de la Convención de Gobernadores de Estados y Territorios Federales. La señaló como necesaria ante la ausencia de un ideal capaz de obligar al acuerdo de voluntades en Venezuela. Cuando Pérez Jiménez llega a la presidencia, la rescata y sintetiza sus objetivos alrededor de tres postulados: 1. Transformación del medio físico. 2. Mejoramiento de las condiciones morales, intelectuales y materiales de los venezolanos. 3. Reordenamiento institucional del Estado y planificación de carácter racional Para alcanzar tales objetivos habría de aprovecharse el acervo histórico de Venezuela en tanto fuente de valores morales; el uso adecuado de los recursos naturales para impulsar el progreso económico y social; y la estratégica ubicación geográfica del país. Véase: Felícitas López Portillo T., El perezjimenismo: génesis de las dictaduras desarrollistas (México D. F.: Universidad Nacional Autónoma de México, 1986); Rafael Cartay, "La filosofía del régimen perezjimenista: El nuevo Ideal Nacional”, Economía, vol. 34, No 15 (1999): 9; Frank Rodríguez, "La noción de democracia en tiempos de la dictadura militar (1948-1958)", Presente y Pasado. Revista de Historia, año 17, Nº 33 (enero-junio, 2012): 134. 
orden interno, procurando granjearse la legitimidad de la cual carecía debido a sus orígenes golpistas. Así, la inauguración de toda obra de gran magnitud era objeto de amplia divulgación mediática, para asegurarse de que fuese conocida por la mayor cantidad de personas en el país como en el exterior ${ }^{23}$.

Ante la proyección de estabilidad que se adjudicaba la dictadura, El Tiempo mediante su despliegue caricatural se empeñó en resaltar lo contrario. Durante enero de 1958, esta fue caracterizada como sumamente inestable, corrupta, represiva y criminal, opuesta a las libertades ciudadanas y a los Derechos Humanos consagrados por las democracias liberales, de las cuales el recién instaurado Frente Nacional junto al principal órgano informativo gobiernista del país (El Tiempo), se presentaron como sus garantes tras la caída de Rojas Pinilla, ocurrida ocho meses atrás. Muy diciente de ello era el lema del periódico bogotano, adjunto en el cabezote de todos sus números:

“EL TIEMPO está al servicio de los ideales de fe democrática y solidaridad patriótica que el Frente Nacional preconiza, y a cuyo amparo los principios consagrados en la Carta de los Derechos Humanos, como fueros de los pueblos libres, han de ser realidad constante para todos los colombianos"24.

Acontecimientos como el levantamiento de la guarnición de Maracay y el subsiguiente ametrallamiento al Palacio de Miraflores en la madrugada del 1 de enero de 1958, o las jornadas de huelga general del 21 y 22 de enero ${ }^{25}$, contribuyeron a socavar la imagen de pretendida estabilidad y tranquilidad que el gobierno venezolano aspiraba consolidar. Las alusiones a tal aspecto criterial de inestabilidad dentro del corpus de caricaturas correspondieron al 84\% de las referencias. Por lo cual, la figura de Pérez Jiménez apareció frecuentemente encuadrada en viñetas donde está desplomándose de espaldas contra el suelo, sentado en sillas reclinadas a punto de perder el equilibrio, precipitándose por despeñaderos o mostrándose impávido y vulnerable ante elementos significantes de potencial peligro para su integridad. Los encabezados de las viñetas consolidaron tal proyección de inestabilidad, inherente a un régimen

${ }^{23}$ Alejandro Cardozo Uzcátegui, "La propaganda política durante el perezjimenato: en la búsqueda de la legitimidad de ejercicio y la diplomacia velada, 1952-1957”, Tiempo y Espacio vol. 39, N. ${ }^{\circ}$ 52(2009): 204-210.

${ }^{24}$ El Tiempo, Bogotá, 22 de Abril, 1960, 1

25 Para un recuento minucioso de los hechos ver: Eleazar Díaz Rangel, Días de enero: cómo fue derrocado Pérez Jiménez (Caracas: Monte Ávila, 1998). 
tambaleante, con expresiones tan sugerentes como: "De tumbo en tumbo “26 " "En dificultades ${ }^{* 27}$,"Se cayó... se cayó... se cayó ${ }^{28}$, y“"Movimiento sísmico “29 (Figura 1).

Figura 1. Aldor, "Movimiento sísmico"

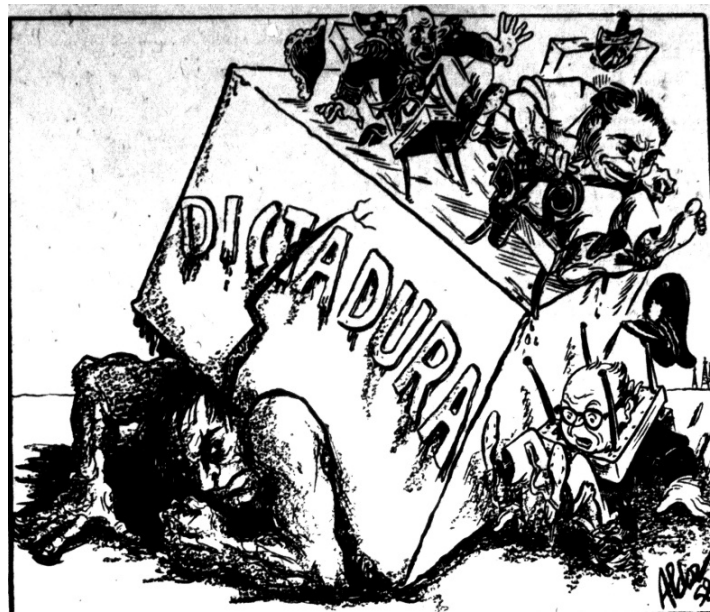

Fuente: El Tiempo, Bogotá 30 de enero, 1958, p. 4.

Los titulares tendieron a reforzar el mensaje transmitido por las imágenes, en el marco del "lenguaje de la caricatura" subyacente en la asociación entre noticias, editoriales e imágenes. A fin de persuadir al público colombiano sobre la inminente caída de la dictadura vecina, se resaltaron expresiones como: "Están contados los días del dictador Marcos Pérez Jiménez" ${ }^{30}$, "Las Fuerzas Armadas presionan sobre Pérez Jiménez"-31, "Pérez Jiménez cedió a la intensa presión militar"32, "Nueva crisis surge en Venezuela. Manifestaciones contra la dictadura en Caracas" ${ }^{* 33}$, "Continúan las protestas en Caracas contra

26 "De tumbo en tumbo", El Tiempo, Bogotá, 8 de enero, 1958.

27 “En dificultades", El Tiempo, Bogotá, 19 de Enero, 1958.

28 “Se cayó... se cayó... se cayó”, El Tiempo, Bogotá, 24 de enero, 1958.

29 “Movimiento sísmico", El Tiempo, Bogotá, 30 de enero, 1958.

30 "Están contados los días del dictador Marcos Pérez Jiménez", El Tiempo, Bogotá, 3 de enero, 1958.

31 “Las Fuerzas Armadas presionan sobre Pérez Jiménez”, El Tiempo, Bogotá, 9 de enero, 1958.

32 "Pérez Jiménez cedió a la intensa presión militar", El Tiempo, Bogotá, 11 de enero, 1958.

33 "Nueva crisis surge en Venezuela. Manifestaciones contra la dictadura en Caracas", El Tiempo, Bogotá, 14 de Enero, 1958. 
Pérez Jiménez" ${ }^{\prime 34}$, "Ultimátum a Pérez Jiménez lanzan jóvenes oficiales" ${ }^{* 35}$, "Cayó Pérez Jiménez ${ }^{* 36}$. Tales expresiones pretendieron poner de manifiesto la supuesta inconformidad del estamento militar venezolano ante la falta de representatividad en favor de una elite personalista, excluyente y corrupta, personificada por Laureano Vallenilla Lanz (Ministro de Relaciones Interiores) y Pedro Estrada (jefe de la Seguridad Nacional, policía política del régimen) ${ }^{37}$.

Una característica usual de los regímenes de fuerza es la represión desplegada contra quienes se disponen a cuestionar el estado de cosas imperante. Las dictaduras identifican como potenciales actores de perturbación a la prensa, el estudiantado, los campesinos, los sindicatos, los intelectuales, el profesorado, las agremiaciones profesionales, entre otros. Estos son objeto de coerción física, intelectual e informativa.

El autoritarismo latinoamericano no permaneció al margen de tal accionar, en particular el régimen de Pérez Jiménez, cuyas medidas represivas permearon considerablemente el transcurrir de la cotidianidad venezolana. Dentro del corpus de caricaturas, los aspectos criteriales alusivos a represión correspondieron al 21\% de las referencias. Los caricaturistas de El Tiempo fueron insistentes en forjar una representación de la dictadura venezolana contraria a la libertad ciudadana, que les restringía a los ciudadanos el amplio uso de los derechos amparados por los regímenes democráticos.

Las representaciones caricaturales vinieron dadas por la frecuente aparición de grilletes y cadenas ancladas a los tobillos de campesinos con mal semblante. Asimismo con la aparición de un Pérez Jiménez ataviado de armamento, presto a sofocar cualquier atisbo de rebelión, que él mismo llegaría a minimizar como simples" "escaramuzas" ${ }^{* 38}$ (Figura 2).

34 "Continúan las protestas en Caracas contra Pérez Jiménez", El Tiempo, Bogotá, 15 de enero, 1958.

35 “Ultimátum a Pérez Jiménez lanzan jóvenes oficiales", El Tiempo, Bogotá, 23 de enero, 1958.

36 "Cayó Pérez Jiménez", El Tiempo, Bogotá, 23 de enero, 1958.

37 Rafael Simón Jiménez M., Militares contra militarismo. La resistencia militar a las dictaduras de Juan Vicente Gómez y Marcos Pérez Jiménez (Caracas: El Centauro Ediciones, 2008), 130.

38 "Fue sofocado ayer el levantamiento de Maracay. A las 3 y 30 cesó la resistencia de los sublevados“, El Tiempo, Bogotá, 3 de enero, 1958, 6 
Figura 2. "El pueblo venezolano:- Siempre es que hay una pequeña diferencia" Chapete, "Maracas para un joropo"

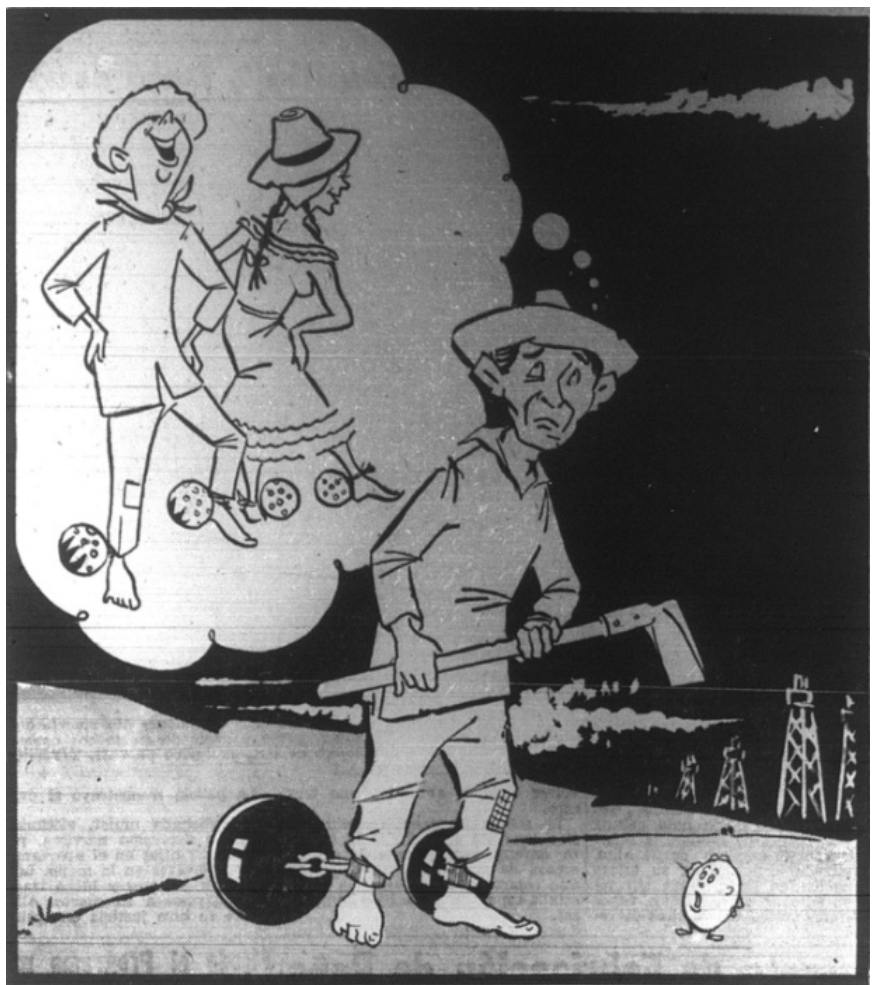

Fuente: El Tiempo, Bogotá, 11 de enero, 1958, p. 4.

Los titulares de primera página reforzaron el mensaje expuesto por las viñetas, subrayando el accionar de una dictadura que se inmiscuía continuamente en todo espacio social susceptible de resguardar algún indicio de criticismo, por percibirlo como un peligro contra la continuidad del Nuevo Ideal Nacional (Rabe, 1988). Persuadir al público colombiano de esto, condujo a la frecuente aparición de titulares del siguiente cariz: "Persecución a la prensa en Venezuela"39,"Detenidos los directores de La Religión y La Esfera"40," Cortina de silencio tiende la dictadura sobre Caracas"41, "Detenidos más profesores y

\footnotetext{
39 "Persecución a la prensa en Venezuela", El Tiempo, Bogotá, 5 de enero, 1958.

40 "Detenidos los directores de La Religión y La Esfera”, El Tiempo, Bogotá, 5 de enero, 1958.

41 "Cortina de silencio tiende la dictadura sobre Caracas", El Tiempo, Bogotá, 6 de enero, 1958.
} 
obreros en Caracas" ${ }^{* 42}$,"La policía dispara contra los estudiantes en Caracas" ${ }^{* 43}$, "Drástica represión lleva a cabo el régimen de Pérez Jiménez" ${ }^{-44}$, y "Centenares de muertos en Venezuela“" ${ }^{45}$. La proliferación de términos y expresiones como: persecución, cortina de silencio, detenidos, la policía dispara, drástica represión, centenares de muertos, son muy dicientes del propósito del diario liberal por subrayar connotaciones denigratorias a un gobierno adverso a la movilización critica del pueblo venezolano.

De tal manera el diario colombiano contribuyó a acentuar la imagen negativa que pretendía instaurar de la dictadura venezolana, esgrimiendo crudas descripciones del ambiente hostil contra el ejercicio de los derechos y libertades ciudadanas ante el despliegue de un variado catálogo de recursos, consistentes en el accionar de la policía política mediante torturas, campos de concentración, detenciones arbitrarias, persecuciones o asesinatos, contra todo indicio de disensión, como lo señala un editorial:

Tras la cortina de silencio impuesta por la tiranía se movía la trágica máquina de opresión infamante de Pedro Estrada, que no conoció límite alguno de orden legal o moral. Su policía de Seguridad - seguridad para la dictadura- actuaba implacablemente, en una siniestra conjura contra toda noción de humanidad y de justicia. Encarcelamientos sin causa; torturas las más inverosímiles; campos de concentración como el terrible de Guasina; destierros; asesinatos; persecuciones más allá de las fronteras ${ }^{46}$.

Desde El Tiempo, se percibía la insistencia por afirmar la faceta criminal de la dictadura venezolana mediante la representación caricatural de unas manos toscas y manchadas de sangre. Dentro del corpus de caricaturas se identificó un 16\% de referencias alusivas al tópico criminalidad.

\footnotetext{
42 “Detenidos más profesores y obreros en Caracas", El Tiempo, Bogotá, 9 de enero, 1958.

43 "La policía dispara contra los estudiantes en Caracas", El Tiempo, Bogotá, 16 de enero, 1958.

44 “Drástica represión lleva a cabo el régimen de Pérez Jiménez", El Tiempo, Bogotá, 19 de enero, 1958.

45 “Centenares de muertos en Venezuela“, El Tiempo, Bogotá, 23 de enero, 1958.

46 "Rastro de los Hechos", El Tiempo, Bogotá, 26 de enero, 1958.
} 
Figura 3. «...Fuera del escudo...» Aldor, "En Venezuela"

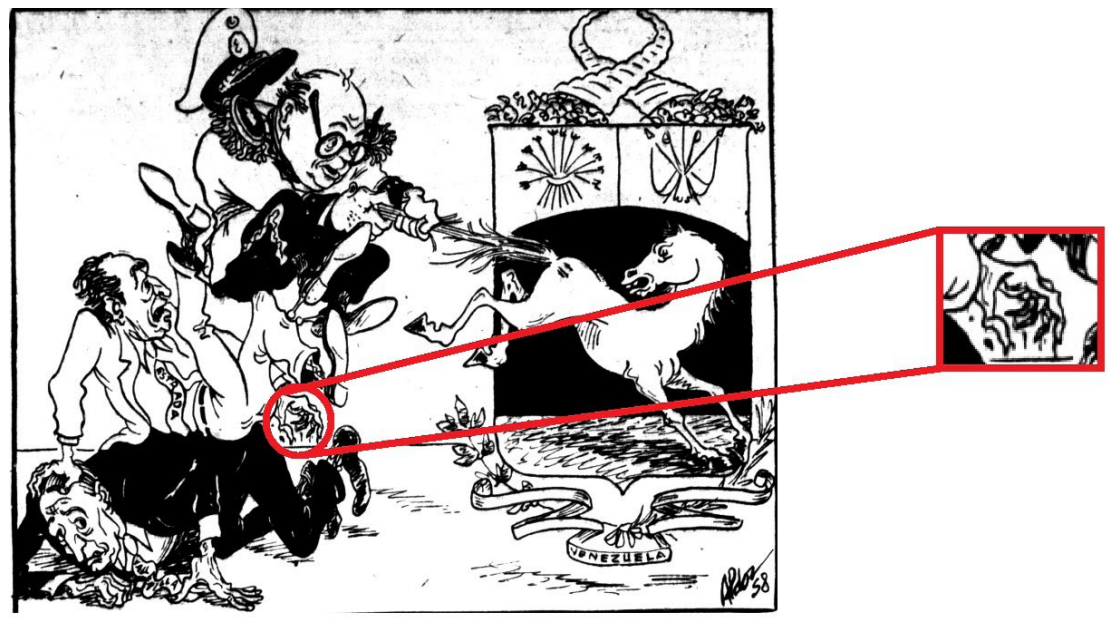

Fuente: El Tiempo, Bogotá, 14 de enero, 1958, p. $4^{47}$.

Lo curioso de tal aspecto criterial, consiste en que su caracterización no fue personalizada en Pérez Jiménez, quien siempre aparece con las manos enguantadas, sino en la figura de Pedro Estrada, jefe de la Seguridad Nacional (SN), adjudicatario de las manos ensangrentadas (Figura 3). Aquí se percibe una separación entre Pérez Jiménez como quien profiere las directrices de asesinato, y Estrada como el ejecutor de estas. No obstante, tal separación no fue más allá del discurso visual, pues en los editoriales se dio por sentado que

${ }^{47}$ En la escena se aprecia a un Pérez Jiménez, apoyado sobre Laureano Vallenilla Lanz y Pedro Estrada, esforzándose por expulsar del escudo venezolano al caballo blanco ubicado en el cuartel inferior. Este diseño heráldico data del decreto emitido por el Congreso Nacional el 18 de abril de 1836, el cual reformaba el escudo de 1830, que lucía igual al de Colombia. En la caricatura la obstinación del dictador venezolano por expulsar al caballo obedece a la significación del animal en la figura, en el marco represivo fomentado por el régimen. Según la Ley de Bandera, Escudo e Himnos Nacionales de 1954:"El tercer cuartel será azul, ocupará toda la parte inferior del Escudo y en él figurará, vuelta la cabeza a la derecha, la figura de un caballo indómito, blanco, emblema de la independencia y de la libertad". Visto de izquierda a derecha, el caballo avanza hacia el futuro, aunque mantiene la vista hacia atrás, pues la conciencia sobre su pasado y el recuerdo de sus gestas históricas le permitirá conservar la libertad y la independencia en su futuro". No por nada Aldor retrató a Pérez Jiménez jalando infructuosamente la cola del caballo, y tambaleándose hacia atrás, al borde de una inevitable caída. Jhonatan Medina Caguana, "Emblemas y empresas en Venezuela. Procesos de traducción y sustitución semiótica en la heráldica sociopolítica contemporánea”, Revista arbitrada de la Facultad de Arquitectura y Diseño de la Universidad del Zulia 2, 22 (julio-diciembre, 2010): 39-41. 
Un par de satrapías en el Caribe. Autoritarismo dominico-venezolano en la caricatura política.

Andrés Murcia Neira

las torturas y asesinatos, indiferentemente del victimario directo, contribuyeron al mismo fin de perpetuar el panorama de corrupción y represión auspiciado por el régimen, como quedó señalado cuando, transcurrido un día desde la caída de la dictadura, se emitieron juicios del siguiente tono:

Desde su exilio el exdictador Pérez Jiménez sus más acuciosos ayudantes, tendrán que sentir ahora-si es que aún les quedan conciencia y vergüenzael terrible arrepentimiento de haber asesinado a un pueblo que tan valientemente quiso combatir por la plenitud de sus fueros ciudadanos. [...] la ambición desorbitada de retener el poder por encima de todo, los precipitó a la locura de la violencia. Y es así como a sus innúmeros crímenes -las deportaciones, las torturas en las cárceles, los misteriosos asesinatos de líderes políticos- se viene a sumar ahora esta terrible hazaña de exterminio con que pretendieron -ya vencidos por el espíritu de su país- sostenerse en el gobierno ${ }^{48}$.

La sangre de las victimas adquirió preeminencia al considerar su derramamiento en beneficio de la continuidad de la dictadura, relacionándola con la estigmatización que en Colombia habían sufrido sectores opuestos a Rojas Pinilla (como el estudiantil) para generar pretextos conducentes a asesinatos masivos, como lo dejó ver El Tiempo al señalar el empeño de Pérez Jiménez por:

sostenerse a costa de cuanta sangre sea preciso derramar. Eso nada podía importarle, eso a ninguno le interesa. Si aquí con un tono imperdonable se atrevieron a calificar a los estudiantes como «sediciosos» que eran necesario exterminar, y eso desde el Ministerio de Educación Nacional, ¿por qué habría de sorprendernos que allá [en Venezuela] haya centenares de muertos y heridos? [A Pérez Jiménez] le fue imprescindible dar largas al asunto, rabioso, queriendo por lo menos dejar tras él muchachos muertos canallamente $^{49}$.

\section{El trujillato desde la caricatura frentenacionalista de El Tiempo}

El giro radical adoptado por la Revolución cubana alarmó al gobierno norteamericano, el cual temía que la subsistencia de dictaduras militares en la región pudiera crear las condiciones para reproducir en otros rincones lo ocurrido en la mayor de las Antillas.

\footnotetext{
48 "Venezuela otra vez patria de la libertad", El Tiempo, Bogotá, 27 de enero, 1958.

${ }^{49}$ Emilia, “jAleluya! Por Venezuela...., El Tiempo, Bogotá, 24 de enero, 1958.
} 
Hacia 1960 la permanencia de Rafael L. Trujillo en República Dominicana se consideró impertinente para los intereses de Estados Unidos. El país del norte se encaminó a movilizar a la opinión pública interamericana contra los regímenes carentes de origen democrático, específicamente en lo que se refería a la Cuba de Fidel Castro ${ }^{50}$.

Una desafortunada serie de actos emprendidos por el régimen dominicano contribuyó a convencer a la opinión estadounidense sobre la inconveniencia de sostener las dictaduras en la región. El 20 de abril de 1960, Trujillo respaldó clandestinamente a un grupo de militares venezolanos, encabezado por el general Jesús María Castro de León, en un levantamiento dirigido a derrocar al presidente Rómulo Betancourt. Dos meses después, el 24 de junio, tuvo lugar la detonación de un carro bomba con el fin de asesinar al presidente venezolano, lo cual inmediatamente dio cabida a acusaciones sobre la implicación dominicana en el atentado por las denuncias del mismo Rómulo Betancourt y gracias a un informe elaborado por una Comisión de Investigación designada por la OEA, determinando que toda la planeación del siniestro ocurrió en Santo Domingo, bajo las instrucciones directas de Trujillo y el jefe del célebre Servicio de Inteligencia Militar (SIM), Johnny Abbes García, quien suministró los explosivos $^{51}$.

El rechazo suscitado por el accionar dominicano fue unánime, lo cual se puso de manifiesto en la VI Reunión de Consulta de Ministros de Relaciones Exteriores de la OEA, celebrada en San José, Costa Rica, entre el 16 y el 21 de agosto de 1960. Allí se acordó emitir una condena contra República Dominicana, por sus actos de agresión e intervención contra Venezuela, al infringir el principio de no intervención consagrado en la Carta fundacional de la organización, y atentar contra la soberanía del país sudamericano. Se determinó la adopción de sanciones como la ruptura generalizada de relaciones diplomáticas de los estados miembro con la isla, y la interrupción parcial de las relaciones económicas, especialmente en lo concerniente al suministro de $\operatorname{armamento}^{52}$.

${ }^{50}$ Stephen G. Rabe, Eisenhower, 155-61.

${ }^{51}$ Héctor Luis Martínez, "Las relaciones Trujillo-Betancourt: ofensiva y contraofensiva de dos políticos paralelos. Un caso de arbitraje de la OEA”, CLÍO 188 (julio-diciembre, 2014): 224.

52 Sexta Reunión de Consulta de Ministros de Relaciones Exteriores. acta final, San José, Organización de Estados Americanos, (16 a 21 de agosto, 1960): 5-6. Disponible en: http://www. oas.org/consejo/sp/rc/RCactas.asp 
Tal panorama de crisis dominicana entre abril y agosto de 1960 fue un marco propicio para construir la representación de una dictadura trujillista encuadrada bajo los tópicos de la criminalidad, la represión y la inestabilidad.

Fue la criminalidad el aspecto criterial con mayor presencia dentro del conjunto de caricaturas relacionadas con Trujillo, correspondiéndole el $55 \%$ de las referencias identificadas. Como en el caso venezolano, las manos manchadas de sangre fueron habituales en la representación caricatural de Trujillo. Su aspecto tosco es resaltado aún más por unos nudillos y falanges magulladas, de magnitud desproporcionada, manipulando armas como revólveres, horcas, cuchillos, bombas, bates con clavos, y jeringas con veneno ${ }^{53}$. Asimismo, la presencia abundante de nutridos apilamientos craneales al lado de Trujillo era una alusión común a las numerosas víctimas asesinadas por la dictadura, en eventos difíciles de ocultar ante la mirada internacional pese al férreo control ejercido sobre todos los informativos de la isla ${ }^{54}$.

El prontuario criminal de Trujillo trascendió fronteras, con la ejecución de asesinatos ordenados por él mismo, como el de Jesús Galíndez y Andrés Requena, en Nueva York; José Almoina, en Ciudad de México; Mauricio Báez, en La Habana, y la posible implicación en la muerte del presidente Carlos Castillo Armas, en Guatemala ${ }^{55}$. Ante ello, proliferaron en El Tiempo titulares del siguiente cariz: "Teniente Jairo Calderón asesinado por Trujillo" ${ }^{* 56}$, "Otros

${ }^{53}$ La jeringa alude al intento de asesinato contra Rómulo Betancourt del 18 de abril de 1951, quien entonces estaba exiliado en La Habana, cuando un agente de Trujillo lo agredió en la calle usando una jeringa con veneno de cobra. Pablo Llabre Raurell, "Trujillo intentó asesinar a Rómulo Betancourt. Atentado en Costa Rica”, Boletín del Archivo General de la Nación año LXXV, vol. XXXVIII, N. 136 (mayo-agosto, 2013): 271.

${ }^{54}$ En 1930, cuando Trujillo ascendió al poder, había tres periódicos en República Dominicana, de propiedad privada y de diversas tendencias políticas: Listín Diario, La Opinión, y La Información. Hacia 1956 los dos periódicos de la capital habían desaparecido. Desde entonces los principales órganos de información eran propiedad de la familia Trujillo: La Nación y El Caribe, ambos dedicados a exaltar la figura de Trujillo. Jesús Galíndez, La era de Trujillo (Santo Domingo: Editorial Letra Gráfica, 2002 [1956]), 221-223.

55 Walter R. Bonilla,, "El terror en República Dominicana durante la era de Trujillo“, Advocatus, N, ${ }^{\circ} 15$ (2010):187-212

56 “Teniente Jairo Calderón asesinado por Trujillo”, El Tiempo, Bogotá, 4 de mayo, 1960. 
crímenes cometidos en Suiza e Italia ${ }^{.57}$,"Crímenes de Trujillo" de agentes de Trujillo ${ }^{-59}$. Siempre el significante Trujillo se vio enmarcado por sustantivos tendentes a ratificar la representación homicida asignada al dictador dominicano, cuyo apellido era percibido como una sinonimia de actos delictivos, una personificación andante de la criminalidad en el plano hemisférico, un remanente anacrónico de tiempos superados y no acorde con la democratización de la región a comienzos de los sesentas:

Trujillo adivinó al poder en uno de esos momentos amargos de la historia americana, cuando subsistían en su vigor la política del «Gran Garrote» y del «Destino Manifiesto». Todo eso ha sido superado. Todo eso es un capítulo vivido y sufrido de una época ya por fortuna quedada atrás en el tiempo y en la conciencia de la solidaridad continental. Hoy Trujillo es un anacronismo. Pero es más aún: un crimen actuante en la existencia del hemisferio ${ }^{60}$.

Figura 4. « ¿Y por qué rompería Colombia relaciones conmigo...?» Aldor, "Meditación en el Caribe“

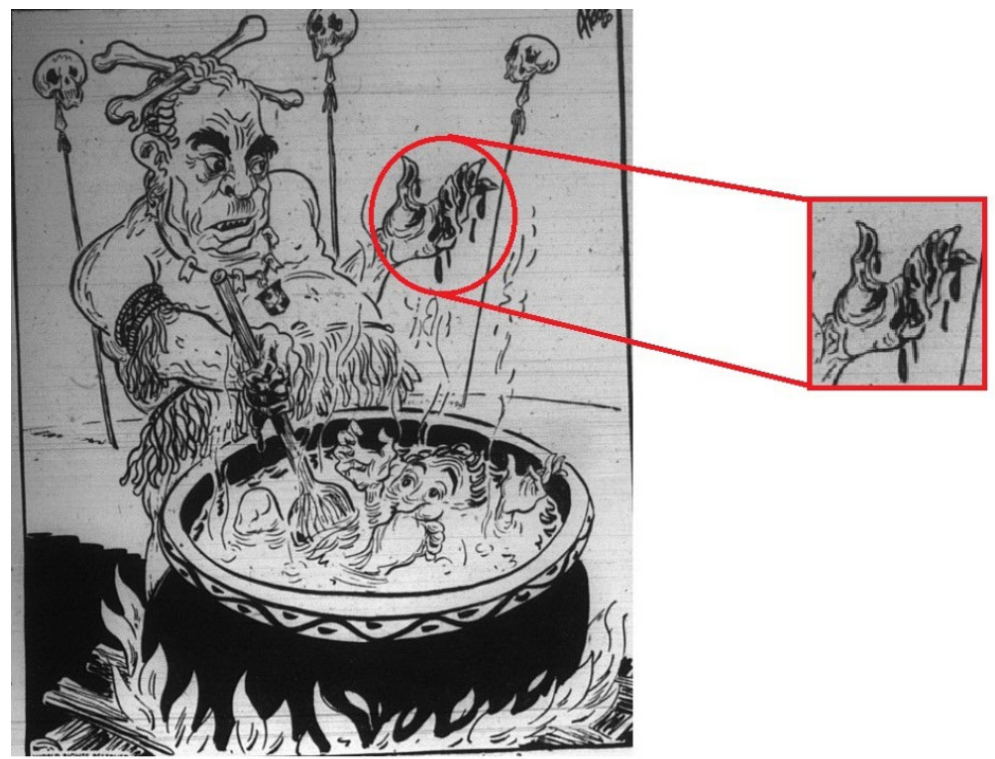

Fuente: El Tiempo, Bogotá, 3 de mayo, 1960, p. 4.

\footnotetext{
57 “Otros crímenes cometidos en Suiza e Italia”, El Tiempo, Bogotá, 18 de mayo, 1960.

58 "Crímenes de Trujillo”, El Tiempo, Bogotá, 19 de mayo, 1960.

59 "La mano homicida de agentes de Trujillo”, El Tiempo, Bogotá, 5 de junio, 1960.

60 "Un crimen contra América”, El Tiempo, Bogotá, 27 de junio, 1960, 4.
} 
Las señales de atavismo fueron muy profusas en las caracterizaciones textuales de Trujillo a fin de articularlas con los elementos exhibidos en las viñetas. Las alusiones a la barbarie del general dominicano, como causa de su conducta asesina, se tradujeron en su vinculación con la figura del caníbal o "monstruo del Caribe" 61 . Al respecto, un editorial del 19 de mayo de 1960, lo calificó como "el típico caudillo de tribu, lleno de plumajes y condecoraciones (parece que es el gobernante más condecorado del mundo, para vergüenza de los donantes), que asocia lo trágico a lo grotesco en proporciones siniestras ${ }^{* 62}$ (Figura 4).

Tal caracterización desde el periódico colombiano, no discordó con la difundida por las expresiones testimoniales del antitrujillismo, las cuales, más llevadas por el odio acérrimo que en fundamentos racionales, subrayaron la faceta primitiva del tirano fundamentada en una presunta herencia de ancestros negros. Así lo puso de manifiesto el español José Almoina (2007), bajo el seudónimo de Gregorio Brutamente, en el libro Una satrapía en el Caribe:

¿Cómo es Trujillo? ¿Tipo normal; tipo anormal? Herencia psicofísica y color. Para juzgar a Trujillo hay que tener en cuenta sus condiciones personales, clave verdadera de todos sus actos, tanto privados como públicos. El dictador es un enfermo mental, tal vez con viejas taras heredosifilíticas, que actúan sobre un complejo negroide muy característico. [...] Han colaborado a esto las gentes que siempre le rodearon, negroides casi todos ellos, gente sin escrúpulos, nacida para la servidumbre y dispuestos a todo con tal de conservar posiciones, dadivas, lujos y prestigios. [...] Recordar esto, es de capital importancia, para entender el proceso mental del Trujillo, primitivo, pre lógico, complicado. [...] Ahora está viviendo Trujillo un momento peligrosísimo, para él y para cuantos le rodean. Sexualmente ha dado en degeneraciones sodomíticas ${ }^{63}$

Con la aplicación de sanciones contra República Dominicana se acentuó la proyección de un régimen inestable, la cual se articuló con las designaciones de decrepitud sobre un gobierno de treinta años, agotado ante las medidas punitivas del sistema interamericano. Las referencias alusivas al tópico inestabilidad, correspondieron al 28\% de las identificadas dentro del corpus.

61 “Acción enérgica y rápida contra Trujillo piden los trabajadores”, El Tiempo, Bogotá, 24 de julio, 1960.

62 “De Oliveira Salazar a Rafael Leónidas Trujillo”, El Tiempo, Bogotá, 19 de mayo, 1960.

63 José Almoina, Una satrapía en el Caribe (México D. F.: Letra Gráfica Breve, 2007 [1950]), 101-102. 
Trujillo habitualmente fue encuadrado en viñetas donde es golpeado por objetos contundentes; se encuentra cayendo de espaldas por un despeñadero; deslizándose por pendientes inclinadas y fracturadas a causa de fuertes movimientos sísmicos; o montando un caballo sumamente extenuado y a punto de desfallecer ante el largo recorrido emprendido por un Trujillo de apariencia decrépita (Figura 5).

Figura 5. “...el rompimiento de relaciones con Trujillo" Aldor, "Se va quedando solo”

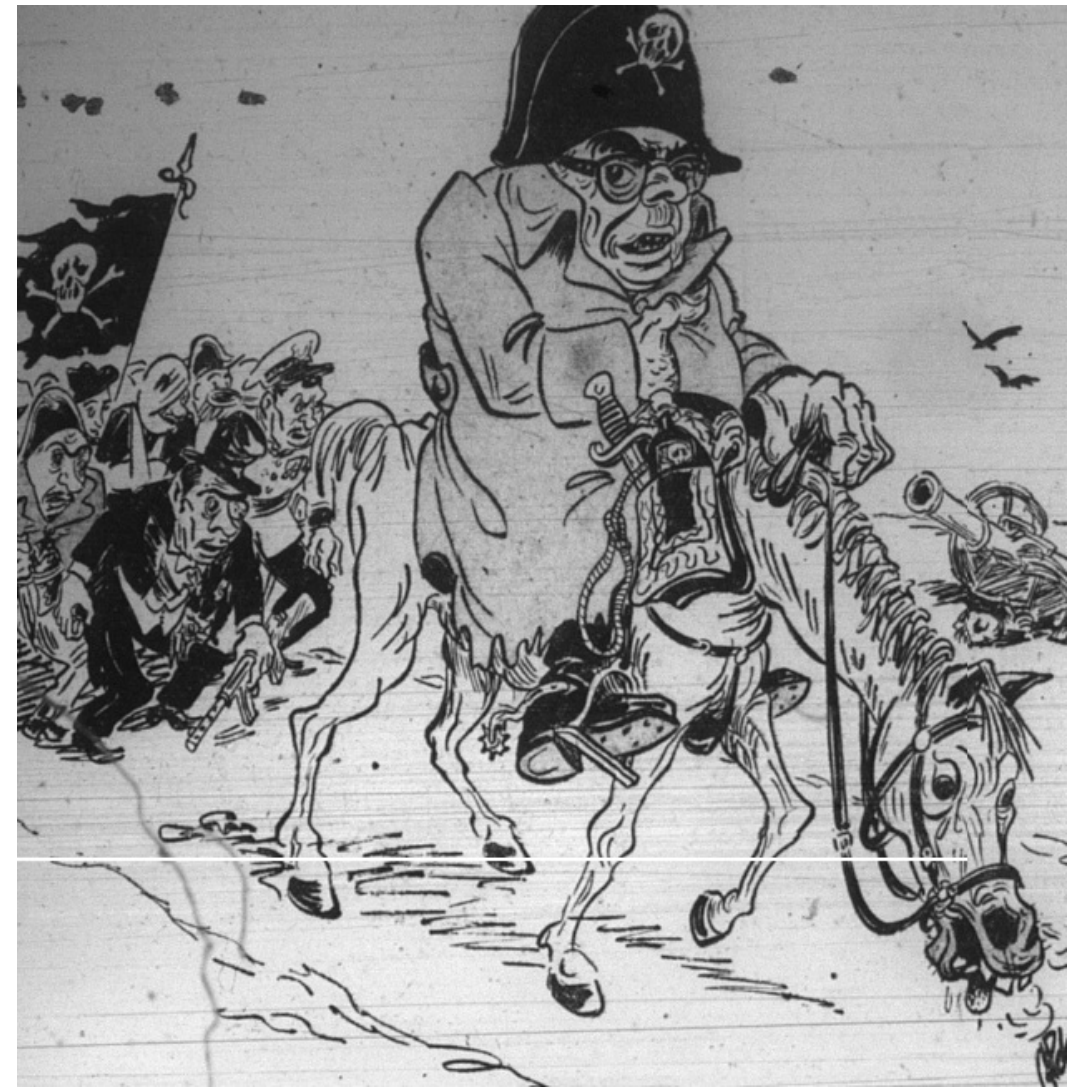

Fuente: El Tiempo, Bogotá, 25 de mayo, 1960, p. 4.

$\mathrm{Al}$ respecto, tal caracterización fue recogida por una caricatura de Aldor, publicada el 25 de mayo de 1960. La viñeta evoca a un Trujillo con traje raído, sobre un caballo a punto de desfallecer ante el peso de las iniquidades personificadas por un Trujillo decrépito. Indudablemente se relacionó con el lema de la campaña presidencial de 1942 emprendida por el dictador 
dominicano: “¡Y seguiré a caballo!". La expresión adquirió popularidad gracias a un merengue compuesto por Pedro N. Pérez en 1947, e interpretado por Rafaelito Martínez ${ }^{64}$. El dictador consideró el merengue un eficaz instrumento de propaganda, al darle la oportunidad de musicalizar loas y versos referentes a los logros de su gobierno, la riqueza del país, la debilidad de los enemigos del Benefactor ${ }^{65}$, la grandeza de su dictadura y la importancia de las Fuerzas Armadas ${ }^{66}$.

Los encabezados tendieron a acentuar la frágil posición de la República Dominicana, sujeta a un aislamiento y rotundo rechazo por parte de la comunidad internacional contra el proceder de su gobierno, con expresiones como: "Partidos peruanos respaldan al gobierno en ruptura con Trujillo" ${ }^{* 67}$, "Bolivia rompe con el gobierno de Trujillo"68, "Venezuela declararía la guerra a Santo Domingo ${ }^{* 69}$, "Anuncian bombardeo a Ciudad Trujillo"70, "Venezuela pide expulsar a Santo Domingo de la OEA" ${ }^{\cdot 71}$,"Piden en México rompimiento de relaciones con Trujillo ${ }^{\cdot 72}$,"Cinco partidos de América piden el bloqueo de Trujillo" ${ }^{73}$,"Sanciones para Santo Domingo pedirán en Costa Rica, Colombia

${ }^{64}$ Dice la letra: "Y seguiré a caballo/ eso dijo el General/Y seguiré a caballo / le dijo a la comisión. / Y ella muy orgullosa/ interpreta la expresión/ porque siguiendo a caballo/ sigue salva la nación./Y el pueblo orgulloso/ aclama al Benefactor/insiste en que él acepte/la nueva postulación./Y lleva en su alma/ la frase del inmortal/ dice «Y seguiré a caballo»/ Gloria al General”. Una grabación de buena calidad puede oírse en: https://www.youtube.com/watch?v=NRhRhlcy-SA

65 Título brindado a Trujillo por aprobación unánime del Senado y la Cámara de Diputados en sesiones celebradas el 9 de noviembre de 1932.

${ }^{66}$ Julie Sellers A., Merengue ad Dominican Identity: Music as a National Unifier (North Carolina: McFarland \& Company Inc. Publishers, 2004), 93-94.

67 "Partidos peruanos respaldan al gobierno en ruptura con Trujillo“, El Tiempo, Bogotá, 11 de mayo, 1960.

68 “Bolivia rompe con el gobierno de Trujillo“, El Tiempo, Bogotá, 21 de mayo, 1960.

69 "Venezuela declararía la guerra a Santo Domingo“, El Tiempo, Bogotá, 29 de junio, 1960.

70 “Anuncian bombardeo a Ciudad Trujillo“, El Tiempo, Bogotá, 3 de julio, 1960.

71 "Venezuela pide expulsar a Santo Domingo de la OEA", El Tiempo, Bogotá, 19 de julio, 1960.

72 "Piden en México rompimiento de relaciones con Trujillo", El Tiempo, Bogotá, 22 de julio, 1960.

73 "Cinco partidos de América piden el bloqueo de Trujillo", El Tiempo, Bogotá, 7 de agosto, 1960. 
y Venezuela"74 , "Asilo para Trujillo «en caso necesario» gestionan en Brasil" ${ }^{\circ 75}$, "Estados Unidos no ayudará a quien apoye a Cuba o venda armas a Santo Domingo $^{\cdot 76}$, "Estados Unidos rompió relaciones diplomáticas con Trujillo ${ }^{* 77}$.

Una de las aspiraciones de Trujillo fue configurar una sociedad dominicana con nexos sólidos entre los civiles y las Fuerzas Armadas, a fin de cimentar las bases de respaldo de un régimen duradero. Para tales efectos, la acción política del gobierno se orientó a la imposición de deberes militares sobre los civiles, y de principios civiles sobre los militares ${ }^{78}$, bajo la convicción de que el Ejército era el único capaz de cumplir una labor institucional exitosa, ante la negligencia e indisciplina de la administración civil ${ }^{79}$.

Así, Trujillo suprimió la libertad de expresión, censuró la prensa, estableció una amplia red de espionaje con la colaboración de informantes civiles y empleados públicos, efectuó detenciones arbitrarias al margen de todo procedimiento legal, irrumpió en los envíos de correspondencia privada nacional y diplomática (Figura 6).

Aquel panorama de restricciones fue insistentemente remarcado desde las páginas del El Tiempo en ocasión de la crisis sufrida por el régimen. Las viñetas encuadraron a un Trujillo animalizado en un pulpo, usando sus largos tentáculos para oprimir al pueblo dominicano; portando grilletes para evocar su carácter comisarial por las detenciones arbitrarias; silenciando a un individuo con un grillete anclado al pie, quien sosteniendo una bandera dominicana está a punto de vociferar denuncias contra el régimen; o siendo la personificación de la "dictadura tropical", acompañando al conjunto de vicios que, a juicio del caricaturista, aquejaban al hemisferio: el sectarismo, la ignorancia, la intolerancia y la miseria. El conjunto de referencias alusivas al carácter represivo del régimen trujillista correspondió al 28\% del corpus examinado.

74 "Sanciones para Santo Domingo pedirán en Costa Rica, Colombia y Venezuela”, El Tiempo, Bogotá, 17 de agosto, 1960.

75 "Asilo para Trujillo «en caso necesario» gestionan en Brasil”, El Tiempo, Bogotá, 14 de agosto, 1960.

76 “Estados Unidos no ayudará a quien apoye a Cuba o venda armas a Santo Domingo“, El Tiempo, Bogotá, 25 de agosto, 1960.

77 "Estados Unidos rompió relaciones diplomáticas con Trujillo", El Tiempo, Bogotá, 27 de agosto, 1960.

${ }^{78}$ Valentina Peguero, The Militarization of Culture in the Dominican Republic, from the Captains General to General Trujillo (University of Nebraska Press: 2004), 102.

${ }^{79}$ Ibíd., 104. 
Un par de satrapías en el Caribe. Autoritarismo dominico-venezolano en la caricatura política. Andrés Murcia Neira

Figura 6. "El pueblo dominicano: ¡Socorro!!! ¡Socorro!!!" Chapete, "La bandera ausente"

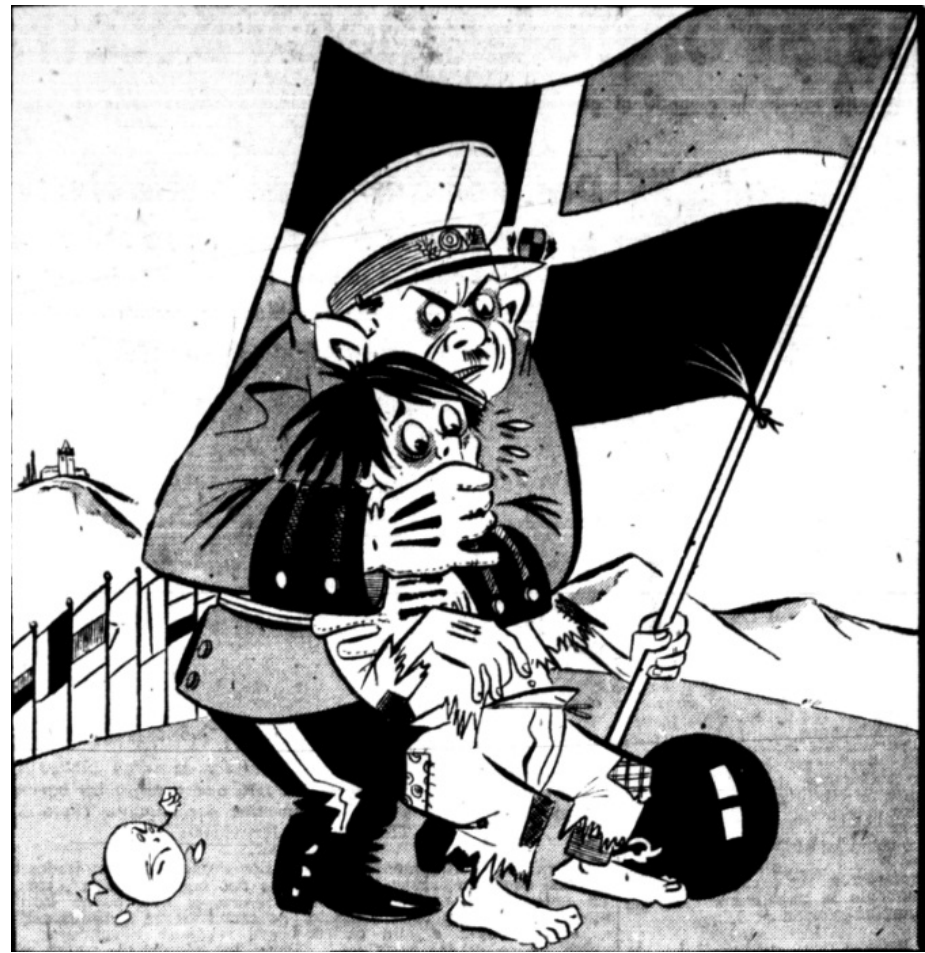

Fuente: El Tiempo, Bogotá, 8 de septiembre, 1960, p. 4.

Las viñetas de El Tiempo recogieron la mayoría de las caracterizaciones conductuales atribuidas a Trujillo, encaminadas a enlazar su apellido con sensaciones de odio, agresión y censura. Varios testimonios sirvieron para expresarlo, como las declaraciones del excónsul dominicano en Holanda, Salvador Barinas Tejera, quien había solicitado asilo en Colombia, al señalar la amplia red de espionaje empleada por el dictador, desde cubanos, venezolanos y colombianos, hasta sectores populares con capacidad de condicionar el libre transcurrir de la cotidianidad dominicana, que debía acoplarse a permanentes expresiones de lealtad a Trujillo:

Barinas hace un recuento escalofriante de los sistemas -hasta ahora desconocidos- de que se sirve el tirano insular para eliminar a sus enemigos... o para hacerlos hablar. «Existe, por ejemplo, una silla eléctrica, instalada en una casa de las afueras de Santo Domingo. Desde luego, no es una silla para matar, aunque muchos se han muerto del susto. Pero los 
presos políticos no lo saben. Así que cuando los sientan allí, falla la moral y confiesan cosas que han hecho contra el gobierno o que nunca intentaron siquiera. Todo para salvarse de la muerte. Si confiesan, y como la silla no es mortal, los fusilan o los desaparecen» [...] «El servicio de espionaje del trujillato es pavoroso. Todos los choferes, limpiabotas, sirvientas del país, son agentes secretos del régimen. En la policía secreta hay colombianos, cubanos, venezolanos, gentes de todas las latitudes, antiguos servidores de las dictaduras suramericanas, que en Ciudad Trujillo encontraron refugio y protección. Lo curioso es que a la postre, cuando han aprendido demasiado, el gobierno los hace desaparecer para evitar que hablen al regresar a sus países» ${ }^{80}$.

Se presentó el odio como principal movilizador de los actos de opresión emprendidos por Trujillo, tratando de fijar ante la opinión colombiana la representación de un gobierno dominicano carente de programa político alguno, sosteniéndose no más que para emprender atentados de terror contra todo actor que pudiera poner en peligro su subsistencia dentro de la isla o en otros países de la cuenca del Caribe:

Hay [...] en la vida oficial dominicana actual, algo que a poco de rozarse con ella se palpa en toda su intensidad: el odio. Varias son las personas por quienes el director de la política de aquel país experimenta un odio persistente, un odio dinámico y tenaz. Entre estas personas están el doctor Alberto Lleras, contra quien la animadversión viene desde haber llegado a la presidencia. El doctor Eduardo Santos a quien se achacan toda suerte de crueldades y explotaciones para quienes están bajo su mando. El doctor Germán Arciniegas blanco de epítetos crudos especialmente después de haber escrito su libro «Entre la Libertad y el Miedo». El ex presidente José Figueres víctima constante del sarcasmo al achacarle actividades comunistas $^{81}$.

\section{Funciones del autoritarismo caribeño caricaturizado ante el escenario colombiano}

Una mirada conjunta a los aspectos criteriales remarcados desde la caricatura política sobre Pérez Jiménez y Trujillo, permite revelar que el régimen venezolano fue percibido como un gobierno más inestable que su

80 "El gobierno de Colombia dio asilo a ex cónsul dominicano en Holanda“" El Tiempo, Bogotá, 10 de junio, 1960, 14.

81 Julio Londoño, "El drama dominicano. Odio y atentados", El Tiempo, Bogotá, 2 de julio, 1960. 
Un par de satrapías en el Caribe. Autoritarismo dominico-venezolano en la caricatura política.

Andrés Murcia Neira

par dominicano; y que este último fue depositario de representaciones más homicidas y represivas (Figura 7).

Figura 7. Distribución porcentual de aspectos criteriales

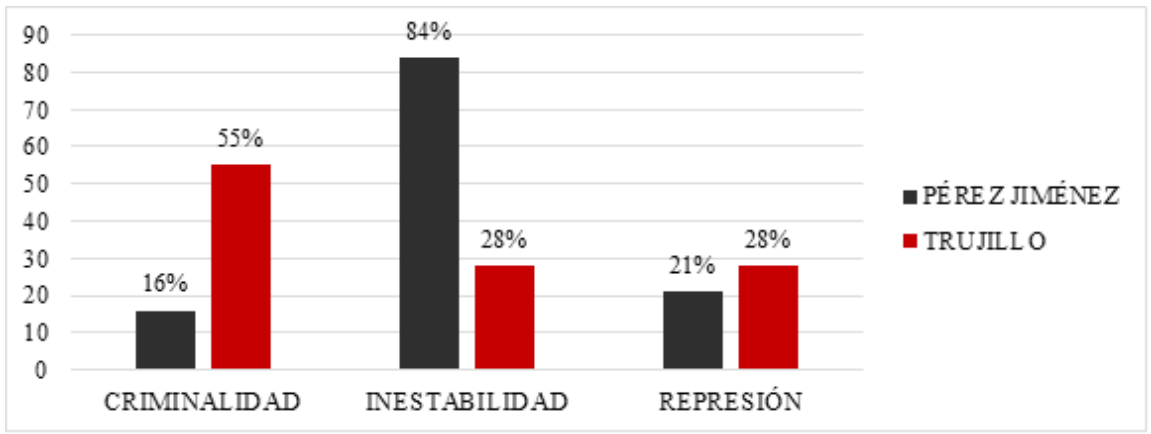

Fuente: elaboración propia.

Indudablemente acontecimientos como el levantamiento de la guarnición de Maracay y el ametrallamiento del Palacio de Miraflores del 1 de enero, junto a la huelga general entre los días 20 y 22 de enero de 1958, contribuyeron a fortalecer la convicción sobre una eventual caída de Pérez Jiménez. Mientras que, por otro lado, las dificultades del régimen dominicano no habrían de ser consideradas suficientes como para deponer un régimen que ya cumplía treinta años entre la jefatura directa de Trujillo y la de gobiernos títere.

En Colombia el recién instaurado Frente Nacional necesitaba granjearse una legitimidad generalizada, subsanando las tradicionales divisiones partidistas y proyectándose como un idealizado régimen democrático, garante de la amplia participación política negada en los tiempos de la dictadura de Rojas Pinilla. La continua caracterización de las dictaduras caribeñas como gobiernos inestables, carentes de bases firmes de respaldo popular, adquirió relevancia al momento de acentuar ante los colombianos las inconveniencias y el temor ante un eventual regreso de la dictadura. Por lo cual, dos habrían de ser las funciones de resaltar el aspecto criterial de inestabilidad.

Por una parte, la construcción negativa atribuida a los regímenes dominicano y venezolano, como inestables y frágiles, contribuiría a fortalecer, por oposición, la imagen de un gobierno colombiano democrático, estable, de armonía y concordia, respetuoso de las libertades, los derechos ciudadanos y la constitucionalidad, a fin de brindarle una identidad cívica y democrática al Frente Nacional mediante la expresión del principal órgano informativo gobiernista: El Tiempo. 
Tanta era la convicción sobre la infalibilidad del nuevo modelo gubernamental instaurado en Colombia, que las exhortaciones para ponerlo en práctica en Venezuela no se hicieron esperar. El Tiempo publicó el 23 de enero, un editorial titulado "El Frente Nacional venezolano". Allí se apeló a una suerte de lectura mecanizada de la historia, según la cual la caída de toda dictadura habida y por haber en América había sido gestionada por la providencialidad de los partidos políticos, en tanto motores indispensables de la democracia representativa,

Si algo enseña la experiencia política de América, es que las dictaduras no se pueden derrocar sino mediante la unión nacional, que se realiza principalmente por medio de los partidos políticos, motores indispensables y naturales de la democracia. En Venezuela, por fin, y abonado por la sangre de los primeros mártires, se gesta ahora la unión de los partidos políticos, en el propio territorio patrio y fuera del país, donde forzosamente se han visto obligados a asilarse los principales jefes de las comunidades políticas independientes ${ }^{82}$.

Por otra parte, la función de tal representación negativa del régimen venezolano, obedeció al fortalecimiento simultáneo de las connotaciones denotativas atribuidas a Pérez Jiménez y al recientemente depuesto Rojas Pinilla. Por ejemplo, durante los críticos sucesos de enero de 1958, El Tiempo dio particular énfasis a la presencia de Rojas y su familia en Ciudad Trujillo ${ }^{83}$. En el marco de la intertextualidad, tal noticia se articuló con los reportajes que acompañaron su publicación, asociando su persona con un conjunto de contrabandistas huyendo de las autoridades ${ }^{84}$ (Figura 8).

No habría de caer en saco roto la alusión a la estancia dominicana de Rojas y su familia, pues en editorial del 24 de enero, tras referir el colapso de la dictadura venezolana y la fuga de Pérez Jiménez hacia Santo Domingo, se procedió a significar a la ciudad caribeña, controlada por Trujillo, como un refugio idóneo para "todos estos" (los tiranos) y sus secuaces, los cuales previamente se habían coaligado para asesinar la libertad en Suramérica; un tiro por elevación para

82 “El Frente Nacional venezolano“, El Tiempo, Bogotá, 23 de enero, 1958.

83 "Rojas Pinilla y sus hijos de nuevo en Santo Domingo“, El Tiempo, Bogotá, 2 de diciembre, 1958.

84 “400 contrabandistas de café están huyendo, dice Téllez Camacho“, El Tiempo, Bogotá, 3 de diciembre, 1958, 1 
Un par de satrapías en el Caribe. Autoritarismo dominico-venezolano en la caricatura política. Andrés Murcia Neira

Rojas Pinilla quien se encontraba implícitamente inscrito en el sustantivo "todosestos":

Al fin el cable comunica vibrante, alegre, que el dictador de Venezuela [...] tuvo que dejar el poder y salir huyendo hacia el refugio de todos estos... Estos... Santo Domingo, naturalmente. [...] Deja tras él, Pérez Jiménez, todo lo que todos dejan: el odio hacia sus pueblos, la saña con que quieren vengarse, de no haber sabido cumplir con ellos, [...] Cae el dictador con todos los que resueltamente lo secundaron para asesinar a los venezolanos, es decir, para asesinar en América del Sur la patria de la Libertad ${ }^{85}$.

Figura 8: "Gurropin:-Estoy maravillado de su obra, Generalísimo Trujillo, lo que siento es no haber llegado yo tan alto..." Chapete, "Entre dictadores"

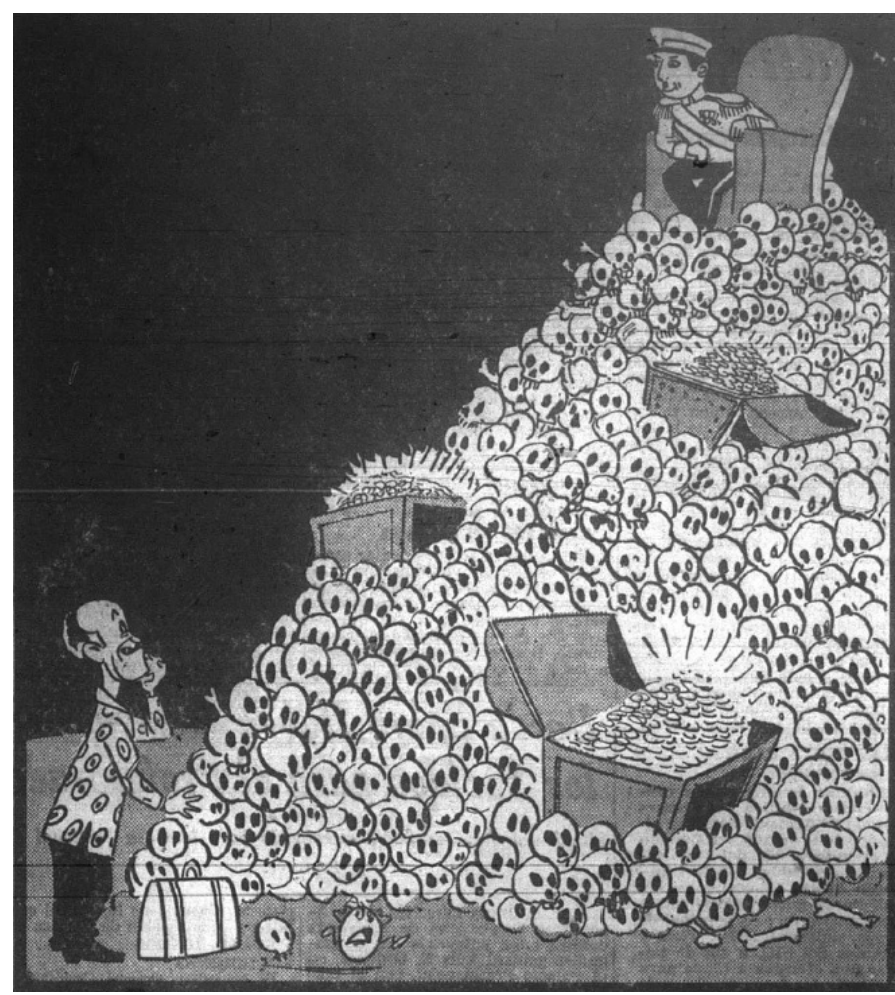

Fuente: El Tiempo, Bogotá, 30 de septiembre, 1957, p. 4.

Los caricaturistas capitalizaron el previo acondicionamiento informativo del accionar de grupos armados (tanto conservadores como liberales) desde los

${ }^{85}$ Emilia, ¡¡Aleluya! Por Venezuela...., El Tiempo, Bogotá, 24 de enero, 1958. 
tiempos de La Violencia, para estrechar su mal recuerdo con la criminalización de Pérez Jiménez y Trujillo. Además de las manos manchadas de sangre, aves rapaces como los buitres o chulos aparecieron en las viñetas como factor alusivo de criminalidad, cumpliendo una doble acepción. Por una parte, la presencia de tales aves portaba una connotación de podredumbre, la presencia de carroña en las cercanías o en el firmamento de cualquier escena donde se hallaran Pérez Jiménez o Trujillo, ocasionada por la proliferación de actos de muerte. Y por otra parte, traía impreso el mal recuerdo de La Violencia conservadora del Valle del Cauca, acometida por los llamados "pájaros", ante lo cual la SN llegó a ser animalizada en la forma de un chulo (Figura 9).

Figura 9. “iAjáa!! ¿̨Con que de a mucho pájaro cogido, eh?” Chapete, "Todo se sabe”

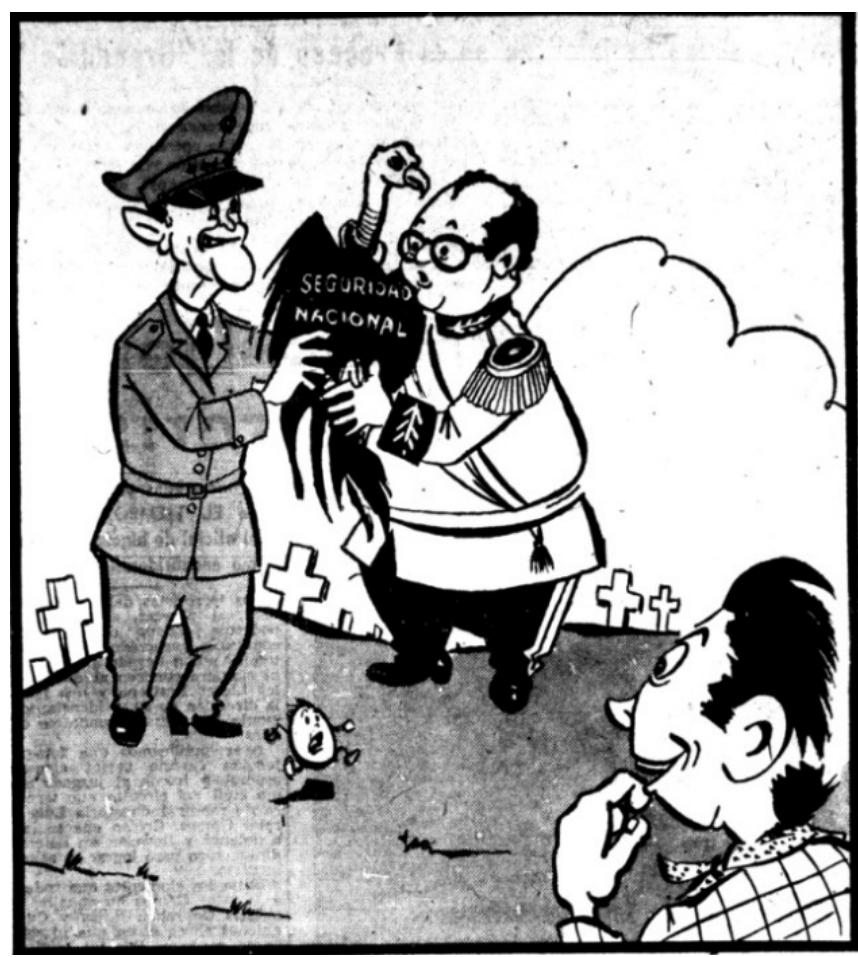

Fuente: El Tiempo, Bogotá, 31 de enero, 1958, p. 4.

Las continuas referencias a la criminalidad del régimen venezolano y dominicano, condujeron a fortalecer la ultrajada representación del depuesto Rojas Pinilla, subrayando sus nexos con León María Lozano "el Cóndor", por quien al parecer el General intercedió durante su estadía en la presidencia, para 
Un par de satrapías en el Caribe. Autoritarismo dominico-venezolano en la caricatura política. Andrés Murcia Neira

liberarlo de prisión en 1953. Simultáneo a los acontecimientos venezolanos, proliferaron titulares consolidando el nexo Rojas-pájaros como: "Altos oficiales declararían sobre la libertad de Cóndor ${ }^{*}$, o “A A quién dio Rojas Pinilla la orden sobre el Cóndor?" ${ }^{27}$. Ante ello, no era raro observar al general colombiano y a Pérez Jiménez siendo objeto de atención en las mismas viñetas.

El Tiempo priorizó representar al Frente Nacional como un gobierno activo en la supresión de los actores de La Violencia que, durante la dictadura militar, operaban sin ningún tipo de obstrucción o consecuencias legales. De ahí, el énfasis puesto en la eficacia de los órganos de seguridad bajo la nueva administración, como el Sistema de Inteligencia Colombiano (SIC) y la Policía, para efectuar su captura y abatimiento. Intención puesta de manifiesto por titulares como: "Tres «pájaros» mueren al enfrentarse a la policía" ${ }^{88}$, "Desde hace seis meses está en la cárcel el jefe del G-2"89, "Muere el temible bandido Milo Cifuentes. Había cometido más de 140 homicidios, la mayoría políticos ${ }^{* 90}$, "La lucha contra La Violencia es el primero de los deberes ciudadanos".91, "Espectacular captura de un peligroso «pájaro». 6 campesinos de Pereira detuvieron al «Mono Triviño» ${ }^{* 92}$.

Las connotaciones represivas atribuidas a la figura de Pérez Jiménez sirvieron para proseguir la campaña de desprestigio contra el depuesto Rojas Pinilla percibido como la principal amenaza contra la concordia y el entendimiento entre los partidos del Frente Nacional indispensable para contrarrestar el totalitarismo, la hegemonía sectarista y la restauración de la dictadura ${ }^{93}$. Para ello se aprovechó la carga negativa adjudicada a los significantes

86 "Altos oficiales declararían sobre la libertad de Cóndor", El Tiempo, Bogotá, 27 de diciembre, 1958.

87 “'A quién dio Rojas Pinilla la orden sobre el Cóndor?”, El Tiempo, Bogotá, 16 de enero, 1958.

88 “Tres «pájaros» mueren al enfrentarse a la policía”, El Tiempo, Bogotá, 4 de diciembre, 1958.

89 “Desde hace seis meses está en la cárcel el jefe del G-2", El Tiempo, Bogotá, 6 de diciembre, 1958.

90 "Muere el temible bandido Milo Cifuentes. Había cometido más de 140 homicidios, la mayoría políticos“, El Tiempo, Bogotá, 28 de diciembre, 1958.

91 "La lucha contra La Violencia es el primero de los deberes ciudadanos", El Tiempo, Bogotá, 2 de enero, 1958.

92 "Espectacular captura de un peligroso «pájaro». 6 campesinos de Pereira detuvieron al «Mono Triviño»", El Tiempo, Bogotá, 3 de enero, 1958.

93 Alberto Valencia Gutiérrez, "El juicio político a Rojas Pinilla en el Congreso de la República (1958-1959) y la conspiración contra el Frente Nacional”, Sociedad y Economía, 18 (2010): 
Pérez Jiménez y Trujillo para transferirla, por asociación, a la figura de Rojas Pinilla, al emplazarlos juntos bajo noticias, editoriales y caricaturas en común.

\section{Conclusiones}

Las representaciones caricaturales asignadas a Pérez Jiménez y Trujillo contribuyeron a atizar facetas como la criminalidad, la represión y la inestabilidad de cada personaje. Contribuyeron a forjar en sus figuras la materialización de los vicios inherentes a unas dictaduras depositarias de todos los desenfrenos contrarios a la democracia como la libertad de expresión, de pensamiento, el respeto a los Derechos Humanos, el equilibrio entre poderes públicos, el sufragio, etc.

El énfasis dado a los tres aspectos criteriales ya citados obedeció a dos funciones. Por una parte, la denostación de tales sistemas dictatoriales permitió revestir al Frente Nacional de una pretendida legitimidad, al presentarlo como un régimen abierto a una amplia participación política, contrariando las restricciones impuestas a los dominicanos y venezolanos a cuenta de aquellos dictadores. Y por otra parte, las connotaciones negativas de Pérez Jiménez y Trujillo, dinamizaron la campaña de ultraje contra el depuesto Rojas Pinilla, entonces personificación colombiana del autoritarismo, respecto al cual se guardaba el temor de un posible regreso para reinstaurar la dictadura.

\section{Referencias bibliográficas}

\section{Fuentes primarias}

\section{Impresas}

\section{Publicaciones periódicas}

El Tiempo, Bogotá, Diciembre (1957), Enero (1958).

El Tiempo, Bogotá, Abril - Octubre. (1960)

\section{Fuentes secundarias}

Almoina, José. Una satrapía en el Caribe. México D. F.: Letra Grafica Breve, 2007 [1950].

Bonilla, Walter R.. "El terror en República Dominicana durante la era de Trujillo". Advocatus 15, (2010).

Cardozo Uzcátegui, Alejandro. "La propaganda política durante el perezjimenato: en la búsqueda de la legitimidad de ejercicio y la diplomacia velada, 1952-1957".

189-90. 
Un par de satrapías en el Caribe. Autoritarismo dominico-venezolano en la caricatura política.

Andrés Murcia Neira

Tiempo y Espacio 39,52, (2009)204-10. http://www.scielo.org.ve/scielo.php?scrip$\mathrm{t}=$ sci_arttext\&pid=S1315-94962009000200002. Consultado 24 de octubre, 2016.

Cartay, Rafael. "La filosofía del régimen perezjimenista: el nuevo Ideal Nacional". Economía 34,15, (1999). ftp://iies.faces.ula.ve/Pdf/Revista15/Rev15Cartay.pdf. Consultado 17 de septiembre, 2016.

Chartier, Roger. El mundo como representación. Estudios sobre historia cultural (Barcelona: Editorial Gedisa, 2005.

Díaz Rangel, Eleázar. Días de enero: cómo fue derrocado Pérez Jiménez. Caracas: Monte Ávila, 1998.

Galíndez, Jesús. La era de Trujillo. Santo Domingo: Letra Gráfica, 2002 [1956].

Gantús, Fausta. "Las caricaturas y la historia política. El caso del México decimonónico." PolHis. Boletín Bibliográfico Electrónico del Programa Buenos Aires de Historia Política 11 (enero-junio, 2013). http://archivo.polhis.com.ar/datos/ Polhis11_GANTUS.pdfConsultado 5 de octubre, 2016.

Garber, William. "Propaganda Analysis-to What Ends?". American Journal of Sociology 48, 2, 240 (September, 1942). http://www.jstor.org/stable/2769619.Consultado 30 de septiembre, 2016.

Hoffer R. Charles."A Sociological Analysis of Propaganda". Social Forces 20, 4 (May1942). http://www.jstor.org/stable/2570877.Consultado 12 de noviembre, 2016.

Jiménez M. y Rafael Simón. Militares contra Militarismo. La resistencia Militar a las Dictaduras de Juan Vicente Gómez y Marcos Pérez Jiménez. Caracas: El Centauro Ediciones, 2008.

Kress, Gunther y Theo van Leeuwen. Reading Images. The Grammar of Visual Design. New York: Routledge, 2006 [1996].

Llabre Raurell, Pablo. "Trujillo intentó asesinar a Rómulo Betancourt. Atentado en Costa Rica.". Boletín del Archivo General de la Nación 38,136 (mayo-agosto, 2013). http://bagn.academiahistoria.org.do/boletines/boletin136/BAGN_2013_ No_136-04.pdf.Consultado 22 de octubre, 2016.

López Portillo T., Felícitas. El perezjimenismo: génesis de las dictaduras desarrollistas. México D. F.: Universidad Nacional Autónoma de México, 1986.

Louis A. Pérez. Cuba in the American Imagination. Metaphor and the Imperial Ethos. Chapel Hill: The University of North Carolina Press, 2008.

Martínez, Héctor Luis. "Las relaciones Trujillo-Betancourt: Ofensiva y contraofensiva de dos políticos paralelos. Un caso de arbitraje de la OEA“. CLÍO 188 (julio-diciembre, 2014). http://www.clio.academiahistoria.org.do/trabajos/ clio188/Clio_2014_No_188-06.pdfConsultado 21 de septiembre, 2016.

Medina Caguana, Jhonatan. "Emblemas y empresas en Venezuela. Procesos de traducción y sustitución semiótica en la heráldica sociopolítica contemporánea". Revista arbitrada de la Facultad de Arquitectura y Diseño de la Universidad del Zulia 2, 22 (julio-diciembre, 2010).

Ortega Ricaurte, Carmen. Diccionario de artistas en Colombia. Bogotá: Ediciones Tercer Mundo, 1965. 
Peguero, Valentina. The Militarization of Culture in the Dominican Republic, from the Captains General to General Trujillo. University of Nebraska Press, 2004.

Pinto Malaver, Martha Lilian. "' Dictadores! A discreción. Una mirada desde la caricatura de Chapete". Historia Caribe 9, 25 (julio-diciembre, 2014). http:// investigaciones.uniatlantico.edu.co/revistas/index.php/Historia_Caribe/article/ view/1238/949Consultado 7 de agosto, 2016.

Press, Charles. The Political Cartoon. Rutherford: Fairleigh Dickinson University Press, Toronto: Associated University Presses, 1981.

Rabe, Stephen G. Eisenhower and Latin America: The Foreign Policy of Anticommunism. Chapel Hill: The University of North Carolina Press, 1988.

Rodríguez, Frank. "La noción de democracia en tiempos de la dictadura militar (1948-1958)“. Presente y Pasado. Revista de Historia, 33 (enero-junio, 2012).

Sánchez Guevara, Graciela. "La caricatura política: sus funcionamientos retóricos". Razón y Palabra, N. 78 (noviembre-enero, 2011-2012): 1. http://www.razonypalabra.org.mx/varia/N78/2a\%20parte/28_Sanchez_V78.pdf.Consultado 12 de octubre, 2016

Sellers A., Julie. Merengue and Dominican Identity: Music as a National Unifier. North Carolina: McFarland \& Company Inc. Publishers, 2004.

Streicher, Lawrence, "On a Theory of Political Caricature". Comparative Studies in Society and History 9, 4 (July, 1967). http://www.jstor.org/stable/177687.Consultado 4 de noviembre, 2016.

Valencia Gutiérrez, Alberto. "El juicio político a Rojas Pinilla en el Congreso de la República (1958-1959) y la conspiración contra el Frente Nacional”. Sociedady Economía, 18 (2010). http://sociedadyeconomia.univalle.edu.co/index.php/sye/ article/view/103.Consultado 2 de noviembre, 2016.

van Dijk, Teun A. La noticia como discurso. Comprensión, estructura y producción de la información. Barcelona: Paidós Ibérica, 1990 [1980].

Victor S. Navasky, The Art of Controversy New York: Alfred A. Knopf, 2013. 